\title{
O źródłach wieloznaczności pojęcia dyskurs w językoznawstwie (na materiale języków polskiego, rosyjskiego i angielskiego)
}

Marta Noińska | Wydział Filologiczny, Uniwersytet Gdański

\section{Streszczenie}

Słowa kluczowe: źródła polisemii, dyskurs, definicja, językoznawstwo

Dyskurs jest nieostrym i niejednoznacznym pojęciem zarówno w języku ogólnym, jak i specjalistycznym. Artykuł poświęcony jest zagadnieniom polisemii tego terminu w pracach językoznawczych na przykładzie języka polskiego, rosyjskiego i angielskiego. W pierwszej części pracy autorka opisuje użycie leksemów dyskurs, discourse i duckypc w języku ogólnym. W części drugiej analizowane są liczne definicje z zakresu lingwistyki. Autorka wylicza źródła polisemii omawianego terminu w zakresie językoznawstwa, takie jak: interdyscyplinarny charakter pojęcia, użycie wyrazu przez przedstawicieli różnych szkół i dyscyplin językoznawczych, zastosowanie terminu na różnych szczeblach ogólności, moda językowa.

On the sources of the polysemy of the term discourse in linguistics: A comparison of Polish, Russian and English

Abstract

Keywords:

Discourse is a fuzzy and vague concept in both everyday and specialized language. This paper is devoted to the polysemy of the term discourse in linguistics, as exemplified by data from Polish, Russian and English. In the introduction, the author describes the use of the lexemes dyskurs, discourse and дискурс in everyday language. In the second part, the author analyzes a number of definitions of the terms from the field of linguistics. The author lists the following sources of polysemy of the term discourse in the field of linguistics: the interdisciplinary nature of the notion; the use of the term by representatives of various schools of linguistics and various linguistic disciplines; the use of the term at different levels of generality; and linguistic fashion. 


\section{Wprowadzenie}

Zjawisko polisemii występuje powszechnie zarówno w językach naturalnych, jak i sztucznych (zob. Wojan 2010; Wojan 2011). W odniesieniu do stylu naukowego wieloznaczność pojęć wydaje się niepożądana, ponieważ może prowadzić do chaosu terminologicznego (zob. między innymi: Pieńkos 2003: 92; Wojan 2010: 92). W pracach językoznawczych dostrzega się jednak występowanie terminów wieloznacznych o bardzo szerokim polu znaczeniowym, czego znakomitym przykładem jest centralny dla współczesnych nauk humanistycznych termin dyskurs. Teun A. van Dijk przyrównuje dyskurs do pojęć: język, komunikacja, interakcja, społeczeństwo czy kultura, wskazując na ich nieuchronną rozmytość (Dijk, red., 2001: 9). To właśnie wieloznaczność i nieostrość wydają się sprzyjać szerokiemu użyciu wymienionych terminów, cechy te umożliwiają bowiem definiowanie każdego pojęcia zgodnie z kierunkiem prowadzonych badań (por. Wojan 2010). Jak zauważa Aleksander Kiklewicz (2015: 16) w odniesieniu do pojęcia dyskursu,

Tak intensywna idiosynkrazja pojęcia dyskursu, po pierwsze, jest uwarunkowana a m b i s e m i ą, tzn. reinterpretacją kategorii pojęciowych przez badaczy należących do odmiennych formacji naukowych, preferujących odmienne systemy konceptualizacji rzeczywistości. Po drugie, przyczyna rozmycia pojęcia dyskursu tkwi w jego pragmatycznie uwarunkowanym, doraźnym, uzualistycznym zastosowaniu w różnych praktykach badawczych.

W niniejszym artykule zostaje podjęta próba opisu źródeł wieloznaczności terminu dyskurs w polsko-, rosyjsko- i anglojęzycznych pracach językoznawczych.

\section{Użycie leksemów dyskurs, discourse, дискурс w językach: polskim, angielskim i rosyjskim}

Na wstępie warto przyjrzeć się etymologii oraz definicjom słownikowym leksemów dyskurs, discourse oraz duckypc we współczesnym języku polskim, angielskim i rosyjskim. Pol. dyskurs, ang. discourse i ros. дuскурс pochodzą od łacińskiego słowa discursus 'rozmowa', 'rozprawa', 'rozumowanie', 'omawianie', które z kolei związane jest z czasownikiem discurrere, oznaczającym 'biegać tam i z powrotem', 'biegać w różnych kierunkach' (zob. Encyklopedia PWN; Słownik języka polskiego pod red. W. Doroszewskiego; Oxford English Dictionary; Большой толковый словарь русского языка pod red. S. Kuzniecowa).

W znaczeniu 'rozmowa', 'dyskusja', 'przemowa' dyskurs odnotowany został w Słowniku języka polskiego pod redakcją Witolda Doroszewskiego (1958-1969). Co ciekawe, w słowniku tym odnaleźć można także czasownik dyskursować w znaczeniu 'prowadzić rozmowę', 'dyskutować. Współczesny Słownik języka polskiego PWN (2017) definiuje jedynie rzeczownik dyskurs: 
1. dyskusja na tematy naukowe

2.wywód przeprowadzony na zasadzie ściśle logicznego wnioskowania.

Definicje słownikowe nie przedstawiają w sposób wyczerpujący tej wielości znaczeń, jakie posiada leksem dyskurs we współczesnej polszczyźnie. Małgorzata Lisowska-Magdziarz wskazuje następujące zastosowania omawianego pojęcia w polszczyźnie ogólnej (Ostrowicka 2014: 49 za Lisowska-Magdziarz 2006):

1. dyskurs jako język w użyciu, np. dyskurs debat sejmowych;

2. dyskurs jako sposób używania języka charakterystyczny dla określonej osoby, zbiorowości lub instytucji, np. dyskurs akademicki;

3. dyskurs jako zdarzenie komunikacyjne o charakterze jednostkowym;

4. dyskurs jako interakcja między jednostkami lub grupami, między jednostką a grupą, utożsamiany z wymianą opinii, debatą, dyskusją;

5. dyskurs jako sposób użycia języka, który jest charakterystyczny dla określonej sytuacji społecznej, np. dyskurs lekcji w szkole;

6. dyskurs jako zespół wartości oraz poglądów na jakiś temat wraz ze specyficznym sposobem ich wyrażania, np. dyskurs neoliberalny.

Jak widać, pojęcie dyskursu jest w ogólnym języku polskim niezwykle szerokie i nieostre, zawsze wiąże się jednak z procesem komunikacji'.

Jedną z przyczyn wieloznaczności leksemu dyskurs wydaje się jego szczególna popularność, na co zwraca uwagę między innymi Dorota Brzozowska (2009a: 12; 2014: 128). „Moda językowa” powoduje, że stosuje się go w najróżniejszych kontekstach zamiast słów aktualnie mniej modnych takich jak język, tekst, wypowiedź czy styl. Co ciekawe, już pod koniec ubiegłego stulecia termin dyskurs często pojawiał się w prasie jako „bliżej nieokreślone pojęcie komunikacji językowej” (Duszak 1998: 14).

Anna Duszak (1998: 14) dostrzega rozbieżności pomiędzy stosowaniem leksemów dyskurs i discourse w ogólnym języku polskim i angielskim oraz większe zakorzenienie omawianego terminu na obszarze anglojęzycznym. Trzeba jednak zaznaczyć, że w omawianych językach z czasem użycie słów dyskurs i dicourse upodobniło się, co można wyjaśnić wpływem języka angielskiego na współczesną polszczyznę. Longman Dictionary of Contemporary English (2017) odnotowuje trzy znaczenia rzeczownika discourse, które nie odbiegają w sposób wyraźny od aktualnych polskich znaczeń przytoczonych powyżej:

1. a serious speech or piece of writing on a particular subject;

2. serious conversation or discussion between people;

3. the language used in particular types of speech or writing.

\footnotetext{
${ }^{1}$ Należy jednak zaznaczyć, że dyskurs nie musi być zawsze związany z komunikacją, istnieją bowiem również dyskursy niekomunikacyjne. Kiklewicz (2015: 38) postuluje, by dyskurs „traktować jako kategorię działalności językowej (tzn. działalności za pośrednictwem języka) niezależnie od specyfikacji jej kontekstu i uwarunkowań zewnętrznych".
} 
We współczesnej angielszczyźnie ogólnej dyskurs rozumiany jest jako 'poważna przemowa lub tekst dotyczący konkretnego tematu'; 'poważna rozmowa lub dyskusja' oraz 'język używany w poszczególnych typach wypowiedzi ustnych i pisemnych'.

Należy zauważyć, że w języku angielskim discourse z akcentem na pierwszą sylabę funkcjonuje jako rzeczownik, zaś z akcentem na ostatnią sylabę - jako czasownik. Słownik oksfordzki języka angielskiego (The Oxford English Dictionary)2 podaje aż dziewięć znaczeń rzeczownika dyskurs, jednakże większość z nich opatrzona została dopiskiem Obs. (= przestarzały) lub arch. (= archaiczny):

1. † Onward course; process or succession of time, events, actions, etc.; $=$ course. Obs.

2. $†$ 'The act of the understanding, by which it passes from premises to consequences' ( $\mathrm{J}$.); reasoning, thought, ratiocination; the faculty of reasoning, reason, rationality. Obs. or arch.

3. † Phr. discourse of reason: process or faculty of reasoning. Obs. or arch.

4. Communication of thought by speech; 'mutual intercourse of language' (J.); talk, conversation. arch.

5. † Narration; a narrative, tale, account. Obs.

6. A spoken or written treatment of a subject, in which it is handled or discussed at length; a dissertation, treatise, homily, sermon, or the like. (Now the prevailing sense.)

7. † a. Familiar intercourse, familiarity. b. Familiarity with a subject; conversancy (in). Obs.

8. Comb. discourse-books

9. Special Comb.: discourse analysis Linguistics, a method of analysing the structure of te$x$ ts or utterances longer than one sentence, taking into account both their linguistic content and their sociolinguistic context; analysis performed using this method.

Additions 1993

Add: [3.] e. Linguistics. A connected series of utterances by which meaning is communicated, esp. forming a unit for analysis; spoken or written communication regarded as consisting of such utterances. Also transf. in Semiotics. Cf. discourse analysis, sense 8 below.

Według słownika oksfordzkiego w języku angielskim dyskurs najczęściej rozumiany jest jako 'szczegółowe omówienie danego zjawiska w mowie lub w piśmie'; 'rozprawa', 'traktat', 'homilia', 'kazanie' (znaczenie 5). Należy dodać, że ten słownik podaje również definicje stricte językoznawcze (dodatek z 1993 roku do znaczenia 3 oraz znaczenie 8).

W ogólnym języku rosyjskim słowo duckypc wydaje się mniej zadomowione aniżeli w języku angielskim czy polskim. Jego definicji nie odnajdujemy w słownikach starszych, na przykład Dala, Uszakowa czy Ożegowa i Szwedowej. Ponadto w wyrazie nie został jeszcze ustalony przycisk artykulacyjny - dopuszczalne są zarówno formy z akcentowaną pierwszą, jak i drugą zgłoską. Новый словарь русского языка (Ефремова 2000) definiuje dyskurs jako rozmowę będącą obiektem badań językoznawczych lub dowód logiczny:

${ }^{2}$ The Oxford English Dictionary (OED) uznawany obecnie za najpełniejszy słownik języka angielskiego. 
1. Разговор, беседа как объект лингвистического исследования.

2.Логический довод, мыслительная посылка.

Большой толковый словарь русского языка pod redakcją Siergieja Kuzniecowa (2014) również określa dyskurs jako obiekt zainteresowania lingwistów. Pojawia się w nim kolejne znaczenie już niespecjalistyczne, a mianowicie dyskurs jako główny sens tekstu (основной смысл текста).

Mimo stosunkowo rzadszego użycia aniżeli w ogólnym języku polskim czy angielskim, rosyjski leksem дискурс występuje nader często w publikacjach naukowych i wchodzi w skład różnych kolokacji, np. медийный, учебный, политический, средневековый, постмодернистский, шизофренический дискурс (Сладкевич 2013: 17). Jego definicje odnaleźć można w encyklopediach i słownikach specjalistycznych (językoznawczych, filozoficznych, socjologicznych). Co ciekawe, дискурс staje się w ostatnim czasie słowem modnym w rosyjskiej prasie (Кашкин 2014: 48).

Jak wykazuje analiza, aktualnie dyskurs, discourse i дискурс są leksemami "modnymi” we wszystkich analizowanych językach. Funkcjonują one w ogólnym języku polskim, angielskim i rosyjskim w nieco odmienny sposób, przy czym szczególną uwagę zwraca stosunkowo mniejsze zakorzenienie słowa дискурс w języku rosyjskim oraz znacznie większa bliskość semantyczna rzeczowników dyskurs i discourse w języku polskim i angielskim, aniżeli miało to miejsce jeszcze przed dwudziestoma laty. Warto podkreślić przy tym znaczący wpływ języka angielskiego na użycie omawianego słowa w języku polskim.

\section{Wieloznaczność pojęcia dyskurs na gruncie językoznawstwa}

Użycie terminu dyskurs ma nieco odmienną tradycję zarówno w różnych dziedzinach nauki, jak i w poszczególnych językach, co przyczynia się do jego wewnątrzjęzykowej i międzyjęzykowej wieloznaczności. Na gruncie polskich i rosyjskich badań nad komunikacją omawiane pojęcie zyskało na znaczeniu po 1989 roku pod wpływem prac lingwistów, socjologów, psychologów i filozofów języka z zachodniego kręgu kulturowego (por. Dawidziuk 2014: 20).

Aleksander Kiklewicz zwraca uwagę na dywersyfikację terminu dyskurs w pracach naukowych z zakresu językoznawstwa (Kiklewicz 2015: 16; por. Wojan 2010: 55):

[...] dyskurs jest rozumiany jako wszelki proces użycia języka; jako strumień mowy; jako każda jednostka mowy dłuższa od zdania; jako wypowiedź mówiona w opozycji do tekstu pisanego; jako proces komunikacji; jako pragmatyczny wymiar tekstu; jako zbiór norm, zasad, reguł zachowań komunikacyjnych (stosowanych w procesie tworzenia tekstu); jako strumień tekstów połączonych ze sobą wspólnym mianownikiem (celem/funkcją, sferą występowania, tematyką, rodzajem używanego medium); jako rodzaj realizacji kodu kulturowego i ideowego. 
Polisemia pojęcia dyskurs związana jest między innymi z obecnością dwóch paradygmatów w badaniach lingwistycznych - strukturalnego i funkcjonalnego, które kładą nacisk na inne aspekty języka (Schiffrin 2003: 20-21). W podejściu strukturalnym w centrum uwagi znajdują się reguły rządzące strukturą grup zdań (język jako kod), zaś w funkcjonalnym, zwłaszcza w socjolingwistyce, użycie języka w kontekście społeczno-kulturowym (nadrzędne w stosunku do samego kodu) (por. Schiffrin 2003: 20-21; Сладкевич 2013: 18-19).

Kim Ballard (2007: 185) w podręczniku akademickim opisującym strukturę języka angielskiego The frameworks of English przyjmuje, że dyskurs jest jednostką językową w mowie lub piśmie, dłuższą niż zdanie ('a linguistic unit, be it spoken or written, larger than a sentence'), co pozwala jej na analizę struktury wypowiedzi/ tekstów i środków językowych, wpływających na jego poprawność gramatyczną i koherencję. Jednocześnie autorka zaznacza, że pojęcie dyskursu może być rozumiane również jako sposób aplikacji/użycia wiedzy o systemie języka w życiu codziennym (Ballard 2007: 185):

[...] discourse is far more than just the largest unit of linguistic construction. It is the means by which we put our implicit knowledge of lexical, grammatical, and other frameworks to use in our daily encounters and actions. It is, if you like, language let loose upon the world.

Rozumienie dyskursu jako użycia języka związane jest z paradygmatem funkcjonalnym, w którym język analizuje się nie jako system autonomiczny, lecz w powiązaniu z jego funkcją społeczną (Schiffrin 2003: 21). Deborah Schiffrin (2003: 39-41) proponuje definicję na skrzyżowaniu paradygmatu funkcjonalnego i strukturalnego, która pozwala zarówno na analizę struktury, jak i użycia języka w kontekście, określając dyskurs jako wypowiedzi (dicourse is utterances), rozumiane jako skontekstualizowane jednostki produkcji językowej w mowie i w piśmie (units of language production that are inherently contextualised). Monografia amerykańskiej badaczki ukazuje różne podejścia do dyskursu w teorii aktów mowy, socjolingwistyce, etnografii komunikacji, pragmatyce czy analizie konwersacyjnej. To właśnie używanie terminu dyskurs w różnych praktykach badawczych przyczynia się do nieostrości i wieloznaczności terminu.

Niekiedy dyskurs rozumiany jest jako wypowiedź mówiona - w opozycji do tekstu pisanego, co łączy się z analizą konwersacyjną, mającą swój początek w amerykańskich badaniach zachowań językowych (speech, discourse) w kontekście społecznym i kulturowym (Duszak 1998: 17). Anna Duszak odnotowuje, że w wielu pracach związanych z pojęciem dyskursu w centrum uwagi znajdował się właśnie język mówiony i analiza dyskursu początkowo kojarzona była z wypowiedziami ustnymi (np. Stubbs 1983; Schriffin 1994).

Równolegle w Europie rozwijała się lingwistyka tekstu, której obiektem był początkowo tekst pisany. W późniejszym okresie zainteresowania lingwistyki tekstu objęły 
również teksty mówione w szerszym kontekście społeczno-kulturowym, co stało się podstawą dla kolejnych badań nad dyskursem. Szczególną rolę w tworzeniu i rozwijaniu teorii tekstu w językoznawstwie rosyjskim przypisuje się Michaiłowi Bachtinowi i Jurijowi Łotmanowi (Бажалкина 2016: 158).

Pionierka polskich badań nad dyskursem - Janina Labocha (1996: 51) - definiuje dyskurs jako "normę oraz strategię zastosowaną w procesie tworzenia tekstu i wypowiedzi". Na normę składają się wzorce społeczne i kulturowe, a jej rezultatem jest tekst lub wypowiedź o określonych cechach gatunkowych. Dorota Brzozowska zauważa, że "W tej koncepcji widać wyraźne nawiązanie do teorii gatunków mowy M. Bachtina" (Brzozowska 2009b: 37).

We współczesnych pracach językoznawczych pojęcia dyskursu i tekstu często występują obok siebie, jednak ich wzajemny stosunek określany bywa na różne sposoby (por. Сладкевич 2013: 22-25). Katarzyna Wojan (2010: 86) stwierdza arbitralnie:

Wieloznaczność o charakterze polisemii może, oczywiście, istnieć także na poziomie tekstu, co rozumie się tu jako element językowy, istotnie większy niż zdanie. Wieloznaczność obserwuje się szczególnie często i dokuczliwie na poziomie dyskursu, czyli tekstu, który funkcjonuje w konkretnej rzeczywistości treściowej.

Analizując wzajemne relacje pojęć dyskursu i tekstu we współczesnych pracach językoznawczych, Żanna Sładkiewicz (Сладкевич 2013: 28) zauważa, że w lingwistyce tekst rozumiany jest $z$ reguły jako abstrakcyjna formalna konstrukcja, zaś dyskurs jako różne rodzaje realizacji tej konstrukcji rozpatrywane przez pryzmat procesów myślowych i czynników pozajęzykowych:

[...] в современной лингвистике под текстом понимается абстрактная, формальная конструкция, под дискурсом - различные виды ее речевой актуализации, рассматриваемые сквозь призму ментальных процессов в соотношении с экстралингвистическими факторами.

Urszula Dąmbska-Prokop (2000: 64) przedstawia dwa podejścia do pojęcia tekstu tekst jako "ciąg zdań powiązanych strukturalnie i semantycznie" albo "słowny zapis wydarzenia komunikacji językowej, determinowany przez intencję nadawcy oraz warunki społeczno-kulturowe". Notabene Dąbska-Prokop nie propaguje tej drugiej definicji, ponieważ powoduje ona zatarcie się granicy między tekstem i dyskursem. Badaczka słusznie zauważa, że w wypadku przyjęcia pierwszego podejścia tekst rozumiany jest jako „pojęcie statyczne, produkt procesu posiadający własną strukturę, względnie niezależny od kontekstu" i ma charakter podrzędny w stosunku do dyskursu będącego dynamicznym procesem tworzenia i rozumienia tekstu, tekstem w kontekście funkcjonującym w określonej sytuacji pragmatycznej i realizującym się w określonym gatunku (Dąmbska-Prokop 2000: 65-66). 
Bardzo podobne ujęcie dyskursu odnajdujemy w klasycznej dla rosyjskiego językoznawstwa definicji Nadieżdy Arutiunowej (Арутюнова 1990: 136-137):

Диску́рс (от франц. discours - речь) - связный текст в совокупности с экстралингвистическими-прагматическими, социокультурными, психологическими и другими факторами; текст, взятый в событийном аспекте; речь, рассматриваемая как целенаправленное социальное действие, как компонент, участвующий во взаимодействии людей и механизмах их сознания (когнитивных процессах). Дискурс - это речь, «погружённая в жизнь».

Na rolę szeroko pojętego kontekstu zwracają również uwagę przedstawiciele multimodalnej analizy dyskursu, Gunther Kress i Theo van Leeuwen, którzy pod omawianym pojęciem rozumieją społecznie osadzone formy wiedzy o (aspektach) rzeczywistości (Kress, Leeuwen 2001: 20-21):

Discourses are socially situated forms of knowledge about (aspects of) reality. This includes knowledge of the events constituting that reality (who is involved, what takes place, where and when it takes place, and so on) as well as a set of related evaluations, purposes, interpretations and legitimations.

Należy jednak podkreślić, że w powyższej definicji leksem dyskurs używany jest jako pojęcie o mniejszym stopniu ogólności i występuje w liczbie mnogiej. David Machin i Andrea Mayr (2012: 20) również definiują dyskurs na dwóch poziomach ogólności: w znaczeniu szerokim - jako język w prawdziwych kontekstach użycia ('language in real contexts of use'), w węższym zaś jako określony model rzeczywistości ('model of the world').

Natalia Bażałkina, rozpatrując różne podejścia do pojęcia dyskurs w rosyjskich i obcojęzycznych pracach językoznawczych, konstatuje, że interpretowane jest ono w sensie ogólnym jako proces komunikacji z uwzględnieniem kontekstu społecznego lub w sensie szczegółowym jako produkt procesu komunikacji - tekst lub zbiór tekstów połączonych ze sobą wspólną tematyką (Бажалкина 2016: 159):

Анализ теоретической литературы показывает, что традиционно в современной лингвистике в зависимости от исследовательских задач дискурс интерпретируется либо в широком понимании как коммуникативный процесс между говорящим и слушающим с учетом определенного социального контекста, приводящий к возникновению текста; либо в «узком» понимании как текст или совокупность текстов (устных и/или письменных) одной тематики (юридический дискурс, педагогический дискурс, политический дискурс и т. д.), т. е. как продукт коммуникативного процесса.

Do takich samych wniosków doszedł wcześniej Teun van Dijk (2001: 12), analizując prace zachodnich lingwistów. Holenderski językoznawca zauważa, że (Dijk, red., 2001: 12): 
Ta wieloznaczność nie sprawia zwykle większego problemu: z kontekstu możemy na ogół wywnioskować, czy w danym przypadku chodzi o znaczenie ogólne czy szczegółowe. Powinniśmy jednak zdawać sobie sprawę z teoretycznej różnicy między abstrakcyjnym znaczeniem 'dyskursu', kiedy odnosimy się do pewnego ogólnego typu zjawisk społecznych, a znaczeniem określonym, kiedy to mamy na myśli konkretną próbkę tekstu lub wypowiedzi.

Stanisław Gajda (1999: 10) odnotowuje więcej, a mianowicie trzy poziomy ogólności stosowania pojęcia dyskursu: 1. jako konkretny, pojedynczy przypadek wydarzenia komunikacyjnego, 2. jako ogólne pojęcie wydarzenia, 3. jako typ wydarzenia.

Jak widać, stosowanie terminu dyskurs jako określenia dla zjawisk o różnym poziomie ogólności stanowi kolejną przyczynę jego wieloznaczności (por. Dijk, red., 2001: 12; Kiklewicz 2015: 24). O ile dyskurs w znaczeniu szerokim wydaje się być pojmowany przez poszczególnych badaczy w podobny sposób (język w użyciu + kontekst społeczno-kulturowy), to znaczenie węższe określane jest w zależności od potrzeb poszczególnych badaczy.

Niekiedy mianem dyskursu w polsko- i rosyjskojęzycznych pracach językoznawczych określa się zjawiska, które mają swoje inne, bardziej tradycyjne, nazwy (tekst, styl, wydarzenie komunikacyjne, ros. речь, функциональный стиль), co można objaśnić wpływem publikacji amerykańskich i zachodnioeuropejskich oraz modą terminologiczną ${ }^{3}$.

\section{Podsumowanie}

Dyskurs jest pojęciem nieostrym i wieloznacznym zarówno w języku potocznym, jak i specjalistycznym. Wielu językoznawców słusznie zwraca uwagę na potrzebę zdefiniowania tego terminu i rozgraniczenia go od fundamentalnych pojęć lingwistyki, takich jak język, styl czy tekst (między innymi: Duszak 1998; Dijk, red., 2001; Kiklewicz 2015; Бжозовская 2014; Чернейко 2014). Lingwiści nie ustają w próbach rozgraniczenia poszczególnych pojęć, aby rozprawić się z powstałym chaosem terminologicznym.

Wśród źródeł polisemii pojęcia dyskursu na gruncie lingwistyki należałoby wymienić:

- interdyscyplinarny charakter pojęcia dyskursi-co za tym idzie - wielość szkółbadawczych posługujących się tym terminem w obrębie różnych nauk humanistycznych;

- użycie terminu przez przedstawicieli różnych paradygmatów językoznawczych (strukturalnego i funkcjonalnego) i różnych dyscyplin językoznawczych (teorii

${ }^{3}$ Należy dodać, że na gruncie rosyjskim i, w nieco mniejszym stopniu polskim, pojęcie dyskursu często postrzegane jest jako konkurencyjne wobec terminu "styl funkcjonalny", co wiąże się z tradycją funkcjonalnej stylistyki, która rozwinęła się w językoznawstwie sowieckim i jest kultywowana również współcześnie. Uwidacznia się tu problem istnienia różnych szkół badawczych o odmiennej tradycji i, co za tym idzie, odmiennej terminologii, zajmujących się podobną problematyką. Integracja różnych podejść nie jest zadaniem łatwym, a swoista globalizacja nauki częstokroć prowadzi do odrzucenia dorobku językoznawstwa „miejscowego" i przyjęcia bardziej rozpowszechnionej i umiędzynarodowionej terminologii i metodologii. 
aktów mowy, socjolingwistyki, etnografii komunikacji, pragmatyki, analizy konwersacyjnej, lingwistyki tekstu);

- użycie terminu na różnych poziomach ogólności - od pojęcia obejmującego wszelkie użycie języka do pojedynczego zdarzenia komunikacyjnego;

- modę językową.

Trzeba zaznaczyć, że popularność pojęcia dyskurs związana jest ze zmianami, jakie zaszły w naukach humanistycznych w ostatnich dekadach i pogłębiającą się interdyscyplinarnością badań. W lingwistyce omawiany termin kojarzony jest z przeniesieniem środka ciężkości z kodu językowego i reguł rządzących systemem językowym na proces komunikacji i użycie języka w szerszym kontekście praktyk społeczno-kulturowych.

\section{Literatura}

Ballard K., 2007, The Frameworks of English. Second Edition, New York: Palgrave.

Brzozowska D., 2009a, Dyskurs i jego kolokacje [w:] Dyskurs w perspektywie akademickiej. Materiały z międzynarodowego okrągłego stołu 3-5 kwietnia 2009 r., Mińsk (Białoruś), Olsztyn: Centrum Badań Europy Wschodniej Uniwersytetu Warmińsko-Mazurskiego w Olsztynie.

Brzozowska D., 2009b, Badania nad dyskursem w polskim językoznawstwie [w:] Dyskurs w perspektywie akademickiej. Materiały z międzynarodowego okrągłego stołu 3-5 kwietnia 2009 r., Mińsk (Białoruś), Olsztyn: Centrum Badań Europy Wschodniej Uniwersytetu Warmińsko-Mazurskiego w Olsztynie.

Dąmbska-Prokop U., 2000, Dyskurs [w:] Mała encyklopedia przekładoznawstwa, red. U. Dąmbska-Prokop, Częstochowa: Wydawnictwo Wyższej Szkoły Języków Obcych i Ekonomii Educator.

Dawidziuk M., 2014, Dyskurs i gatunek wypowiedzi jako podstawowe pojęcia współczesnej lingwistyki - wprowadzenie. „Językoznawstwo: współczesne badania, problemy i analizy językoznawcze” 8. Dijk T.A. van, red., 2001, Dyskurs jako struktura i proces, tłum. G. Grochowski, Warszawa: Wydawnictwo Naukowe PWN.

Duszak A., 1998, Tekst, dyskurs, komunikacja międzykulturowa, Warszawa: Wydawnictwo Naukowe PWN.

Gajda S., 1999, Współczesny polski dyskurs naukowy [w:] Dyskurs naukowy - tradycja i zmiana, red. S. Gajda, Opole: Uniwersytet Opolski. Instytut Filologii Polskiej.

Kiklewicz A., 2015, Kategoryzacja dyskursu [w:] Dyskurs: aspekty lingwistyczne, semiotyczne i komunikacyjne, red. A. Kiklewicz, I. Uchwanowa-Szmygowa, Olsztyn: Centrum Badań Europy Wschodniej Uniwersytetu Warmińsko-Mazurskiego.

Kress G., Leeuwen T. van, 2001, Multimodal Dicourse, Londyn, Nowy Jork: Bloomsbury Academic.

Labocha J., 1996, Tekst, wypowiedź, dyskurs [w:] Styl a tekst: materiały międzynarodowej konferencji naukowej, Opole 26-28.09.1995 r., red. S. Gajda, M. Balowski, Opole: Uniwersytet Opolski.

Lisowska-Magdziarz M., 2006, Analiza tekstu w dyskursie medialnym: przewodnik dla studentów, Kraków: Wydawnictwo Uniwersytetu Jagiellońskiego.

Machin D., Mayr A., 2012, How to Do Critical Discourse Analysis. A Multimodal Introduction, Londyn: Sage. 
Pieńkos J., 2003, Podstawy przekładoznawstwa: od teorii do praktyki, Kraków: Zakamycze.

Schiffrin D., 2003, Approaches to Discourse. Cambridge, MA \& Oxford: Blackwell.

Stubbs M., 1983, Discourse analysis: the sociolinguistic analysis of natural language. Chicago: University of Chicago Press.

Wojan K, 2010, Wstęp do badań wieloznaczności leksemów w ujęciu kontrastywnym, Gdańsk: Wydawnictwo Uniwersytetu Gdańskiego.

Wojan K., 2011, Rosyjskie leksemy homonimiczne w teorii językoznawczej i praktyce leksykograficznej, Gdańsk: Wydawnictwo Uniwersytetu Gdańskiego.

Арутюнова Н.Д., 1990, Дискурс [w:] Лингвистический энциклопедический словарь, Москва: Советская энциклопедия.

Бажалкина Н.С., 2016, К проблеме различных подходов к пониманию дискурса в современном языкознании, «Вестник Кемеровского государственного университета» 1.

Бжозовская Д., 2014, Стиль и дискурс [w:] Дискурс и стиль, ред. Г.Я. Солганик, Н.И. Клушина, Н.В. Смирнова, Москва: Наука.

Кашкин В.Б., 2014, Дискурс: пределы точности [w:] Дискурс и стиль, ред. Г.Я. Солганик, Н.И. Клушина, Н.В. Смирнова, Москва: Наука.

Сладкевич Ж., 2013, Политический фельетон в свете теории речевого воздействия, Gdańsk: Wydawnictwo Uniwersytetu Gdańskiego.

Чернейко Л.О., 2014, Дискурс: языковая реальность или лингвистическая мифология [w:] Дискурс и стиль, ред. Г.Я. Солганик, Н.И. Клушина, Н.В. Смирнова, Москва: Наука.

Słowniki i encyklopedie

Doroszewski W. (red.), 1958-1969, Słownik języka polskiego, Warszawa: Państwowe Wydawnictwo Naukowe, https://sjp.pwn.pl/doroszewski/ [dostęp: 15.06.2017].

Encyklopedia powszechna PWN, 2017, http://encyklopedia.pwn.pl/ [dostęp: 15.06].

Longman Dictionary of Contemporary English, 2017, http://www.Idoceonline.com/ [dostęp: 15.06].

Oxford English Dictionary, 2010, Oxford: Oxford University Press.

Słownik języka polskiego PWN, 2017, http://sjp.pwn.pl/ [dostęp: 15.06].

Большой толковый словарь русского языка, ред. С.А. Кузнецов (1-е издание: 1998), 2017, Санкт-Петербург: Норинт, публикуется в авторской редакции 2014 года, www.gramota.ru [dostęp: 15.06].

Ефремова Т.Ф., 2000, Новый словарь русского языка. Толково-словообразовательный, Москва: Русский язык.

Ожегов С.И., Шведова Н.Ю., 2006, Толковый словарь русского языка, Москва: «А Темп», on-line: http://dic.academic.ru/dic.nsf/enc_philosophy/337/\%D0\%94\%D0\%98\%D0\%A1\%D0\%9A\%D0\%A3\%D0\%A0\%D0\%A1 [dostęp: 15.06.2017]. 